Hydrol. Earth Syst. Sci., 13, 2023-2030, 2009

www.hydrol-earth-syst-sci.net/13/2023/2009/

(C) Author(s) 2009. This work is distributed under

the Creative Commons Attribution 3.0 License.

\title{
Snow distribution over the Namco lake area of the Tibetan Plateau
}

\author{
M. Li ${ }^{1}$, Y. Ma ${ }^{1,2}$, Z. Hu${ }^{1}$, H. Ishikawa ${ }^{3}$, and Y. Oku ${ }^{3}$ \\ ${ }^{1}$ Cold and Arid Region Environmental and Engineering Research Institute, Chinese Academy of Sciences, \\ Lanzhou 730000, China \\ ${ }^{2}$ Institute of Tibetan Plateau Research, Chinese Academy of Sciences, Beijing 100085, China \\ ${ }^{3}$ Disaster Prevention Research Institute, Kyoto University, Kyoto 611-0011, Japan
}

Received: 19 December 2008 - Published in Hydrol. Earth Syst. Sci. Discuss.: 16 February 2009

Revised: 14 September 2009 - Accepted: 14 October 2009 - Published: 2 November 2009

\begin{abstract}
The mesoscale snow distribution over the Namco lake area of the Tibetan Plateau on October 2005 has been investigated in this paper. The base and revised experiments were conducted using the Weather Research Model (WRF) with three nested grids that included a $1 \mathrm{~km}$ finest grid centered on the Namco station. Our simulation ran from 6 October through to 10 October 2005, which was concurrent with long term meteorological observations. Evaluation against boundary layer meteorological tower measurements and flux observations showed that the model captured the observed $2 \mathrm{~m}$ temperature and $10 \mathrm{~m}$ winds reasonably well in the revised experiment. The results suggest that output snow depth maximum amounts from two simulated experiments were centered downwind of the Namco lakeshore. Modified surface state variable, for example, surface skin temperature on the lake help to increase simulated credibility.
\end{abstract}

\section{Introduction}

The Tibetan Plateau, known as the Roof of the World, has been recognized as the heat source/sink in summer/winter for the monsoon circulation over the Tibetan Plateau. In the literature (Hahn and Manabe, 1975; Murakami, 1987; Flohn, 1965; Ye et al., 1993; Chen and Yoon, 2000; Zhang et al., 2002; Waliser et al., 2003; Goswami et al., 2006; Yanai and $\mathrm{Wu}, 2006$; Wu et al., 2007) it has been mentioned as one of the most important factors for the generation and maintenance of Asia summer monsoon circulation and rainfall.

Correspondence to: $\mathrm{M}$. $\mathrm{Li}$

(mshli@lzb.ac.cn)
During summer, the Tibetan Plateau, due to its high elevation, receives a large amount of solar radiation which effectively heats the surface creating a strong heat contrast at the mid-tropospheric level. The sensible heat, as well as latent heat flux released over the Tibetan Plateau, drives the Asian monsoon circulation and strongly influences global circulation patterns (Murakami, 1987). Results (Flohn, 1965) also show that the latent heating plays a more important role than the sensible heating for the maintenance of Asia monsoon. There is a sharp contrast between the western and eastern plateau in terms of precipitation and moisture distribution. Studies (Murakami, 1987) show that the sensible heat flux is extremely large over the arid western Tibetan Plateau during June compared to the eastern side. On the other hand, in the eastern side of the Tibetan Plateau, the latent heat flux is more, so much so that the eastern plateau is described (Luo and Yanai, 1983) as a huge chimney funneling water vapour from the near-surface layer to the upper layer. There is evidence to suggest that the Tibetan snow cover/snow water equivalent largely affects the Asian monsoon rainy season. Results of General Circulation Model (GCM) experiments (Ose, 1996) show that the anomalous tends to produce a weak Asian monsoon cooling due to positive snow mass anomalies in early spring over Tibet. But few studies to lake effect snow phenomena have been implemented on the Tibetan Plateau. There are thousands of lakes across the Tibetan Plateau. Namco is one of the most beautiful and very important places in the Nyainqentanglha mountain range. It is at an elevation of $4718 \mathrm{~m}$, covering an area of $1940 \mathrm{sq} . \mathrm{km}$. (Wang, and Hongsheng, 1998) Lake temperature effect snow occurs frequently over the Namco Lake region during the winter season as cold air outbreaks modify boundary-layer air. In this study, lake temperature effect snow was analyzed

Published by Copernicus Publications on behalf of the European Geosciences Union. 


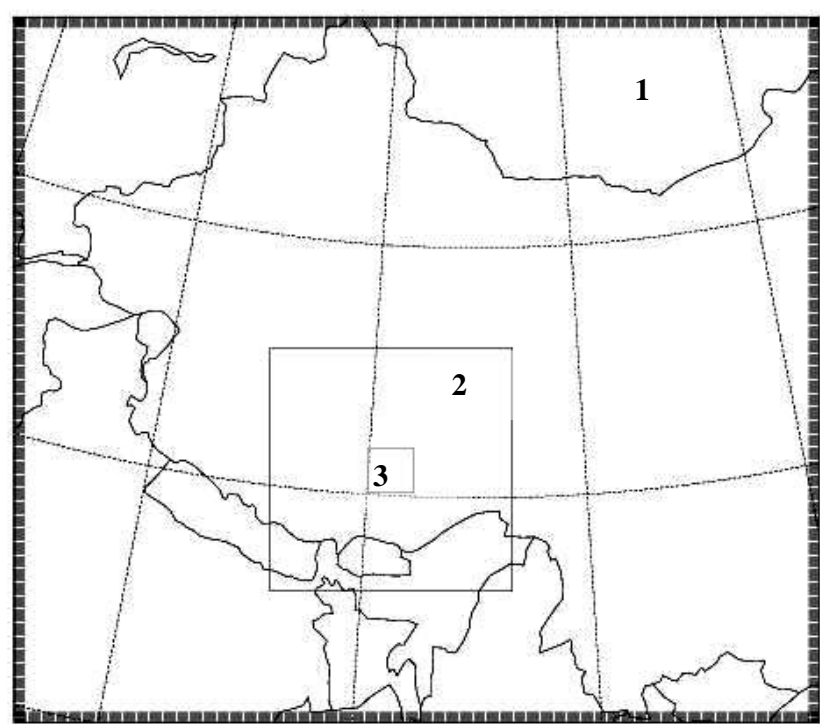

Fig. 1. Model simulation domain of three nested grids. The coarse grid to the finest grid intervals are $9 \mathrm{~km}, 3 \mathrm{~km}$ and $1 \mathrm{~km}$, respectively.

using WRF model. Firstly, the model grid configurations and numerical experiment design are introduced. Then we evaluate the modelled meteorological variables. Revised studies consisting of a decrease of lake surface temperature were compared against a base simulation and some initial results are described. At last, we gave the possible reason for lake temperature effect snow on the Namco Lake area.

\section{Model description and numerical experiment design}

\subsection{WRF model}

The Weather Research and Forecasting (WRF) model (Wang et al., 2006) was been used in this study. We simulate snowfall from 6 October through to 10 October 2005. NCEP fnl data was selected as initial value in the WRF model. The selected physical options are as follows:

Microphysics: WSM6-class scheme;

Longwave radiation: RRTM;

Shortwave radiation: Goddard short wave scheme (CAM);

Land surface scheme: Noah Land surface model;

Cumulus parameterization: Kain-Fritsch scheme;

Planetary Boundary Layer: Yonsei Universrity scheme.

The snow model of Noah LSM has one layer of snow. It simulates the snow accumulation, sublimation, melting and heat exchange at snow-atmosphere and snow-soil interfaces. The precipitation is categorized as snow when the temperature in the lowest atmospheric layer is below $0^{\circ}$. In this snow model, the skin temperature is one of the important state variables. Detailed scheme and physical processes of the snow model are described by (Chen and Dudhia, 2001).

\subsection{Grid configuration and experiment design}

The model domain and grid configuration are shown in Fig. 1. It comprises of three levels of nested grids with the coarsest grid (grid 1) covering the whole Tibetan Plateau area at $9 \mathrm{~km}$ grid spacing, and the finest grid (grid 3) covering an area of $199 \mathrm{~km} \times 199 \mathrm{~km}$, focusing on the Namco area at $1 \mathrm{~km}$ grid increment. The coarse grid time step is $54 \mathrm{~s}$. The model central point is $30.77^{\circ} \mathrm{N}, 90.99^{\circ} \mathrm{E}$, same as the Namco site. The model is driven by 6-hourly lateral boundary conditions derived from the NCEP fnl data.

The experiment started on 6 October 2005 and ended on 10 October 2005, concurrent with the Namco long-term observation. We made two experiments for contrast, one is the base experiment and the another is the revised experiment. In the base experiment, NCEP fnl data is used to drive the WRF model, the output lake skin temperature is always $300 \mathrm{k}$, which due to WRF model uses the constant as the lake skin temperature over the lake surface. In the revised experiment, we change the input lake skin temperature to that from the remote sensing data.

\section{Observations, site description and synoptic situation of October 2005}

Namco Station for Multisphere Observation and Research, Chinese Academy of Sciences (NAMOR/CAS) $\left(30^{\circ} 46.44^{\prime} \mathrm{N}, 90^{\circ} 59.31^{\prime} \mathrm{E}, 4730 \mathrm{~m}\right.$ a.s.1.), located at the southeastern shore of the Namco Lake, northern slope of the Nyainqentanglha Mts, $220 \mathrm{~km}$ away from Lhasa, was established for the long-term observation by the Institute of Tibetan Plateau Research, Chinese Academy of Sciences in 2005. Automatic Weather Stations (AWSs) and hydrologic observation sites had been set up in the south and north of Mt. Nyainqentanglha and around the Namco to collect the basic data in order to understand the climate and hydrology in the Namco region. A $52 \mathrm{~m}$ meteorological tower boundary collects meteorological data in different layers. The eddy correlation and $\mathrm{CO}_{2} / \mathrm{H}_{2} \mathrm{O}$ analysis system measure fluxes of heat, moisture and trace gases at the near surface layer. The aim of collecting data is to study the regional landatmosphere processes, the moisture transport and water cycle, and to add the parameter database of effective land surface process over the Tibetan Plateau. The variations of glacier, snow cover and permafrost were observed for exploring the interactions between cryosphere and climate changes. 

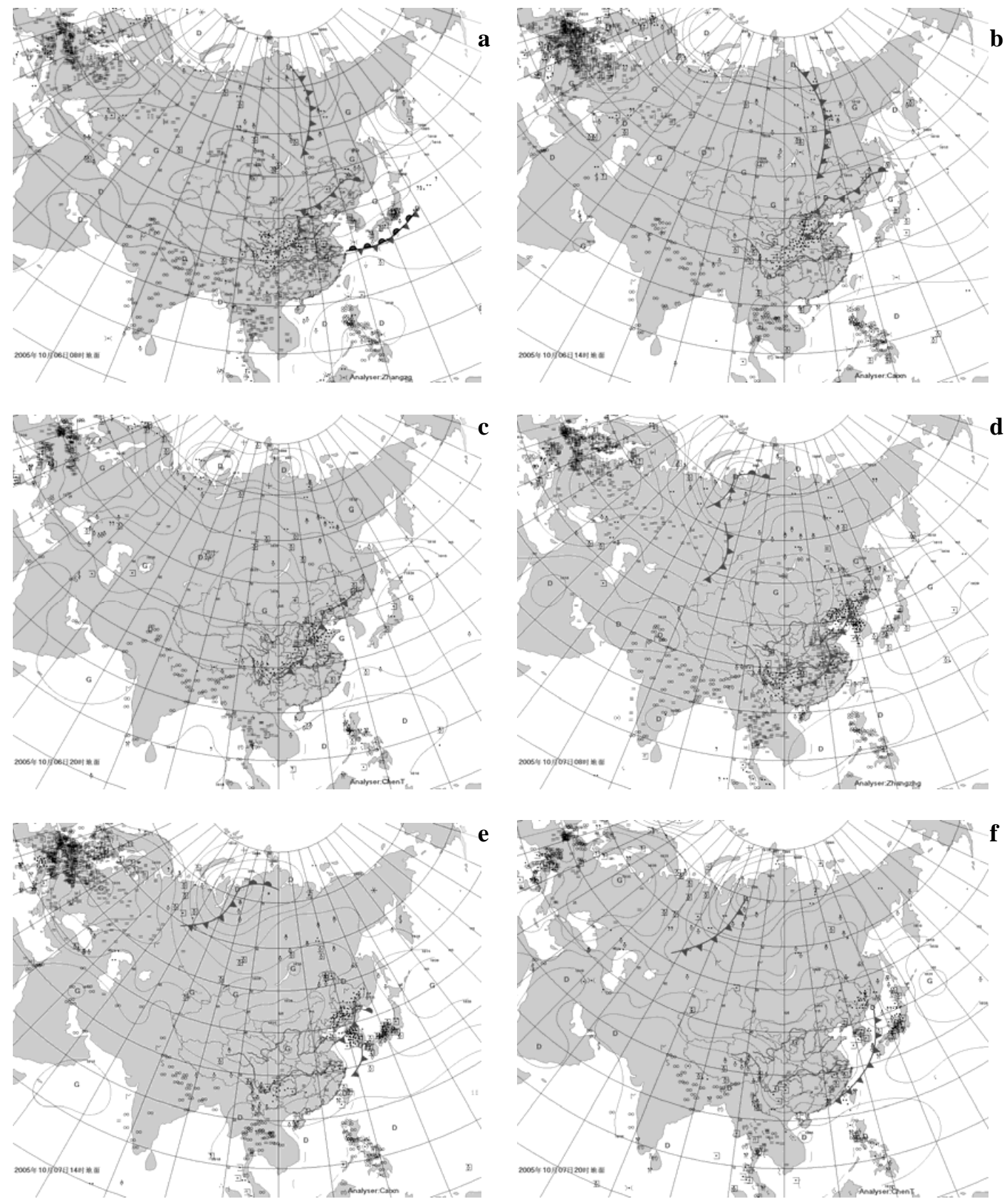

Fig. 2. Surface synoptic chart at 08:00, 14:00, 20:00 BST on 6 October 2005 (a, b, c) and 7 October 2005 (d, e, f).

The detailed descriptions of this station can be found on website http://www.namco.itpcas.ac.cn/introductionen.html.

The synoptic situation for our simulated time period, 6 October through to 10 October 2005, can be summarized as follows: National Meteorological Center of China Meteorological Administration surface synoptic charts show that there is an area of high pressure towards Siberia which extends southwards across Mongolia to the south of China (Fig. 2). The centre of the high pressure moves in a southward direction. The other feature on the chart is the large depression in
India. The block over the Tibetan Plateau has forced the area of low pressure to move south-westwards. Two main cells have formed. The isobars are tightly packed and gale force winds from the northwest are affecting many parts of the Tibetan Plateau. Snow fell over most of the domain during this simulation period. 


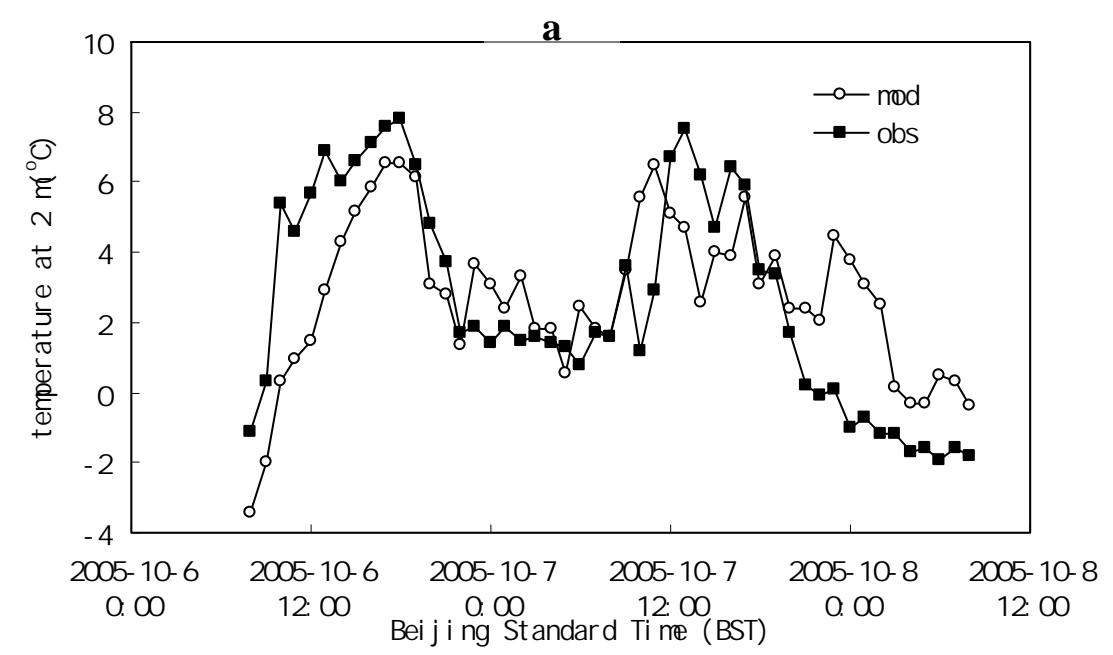

b

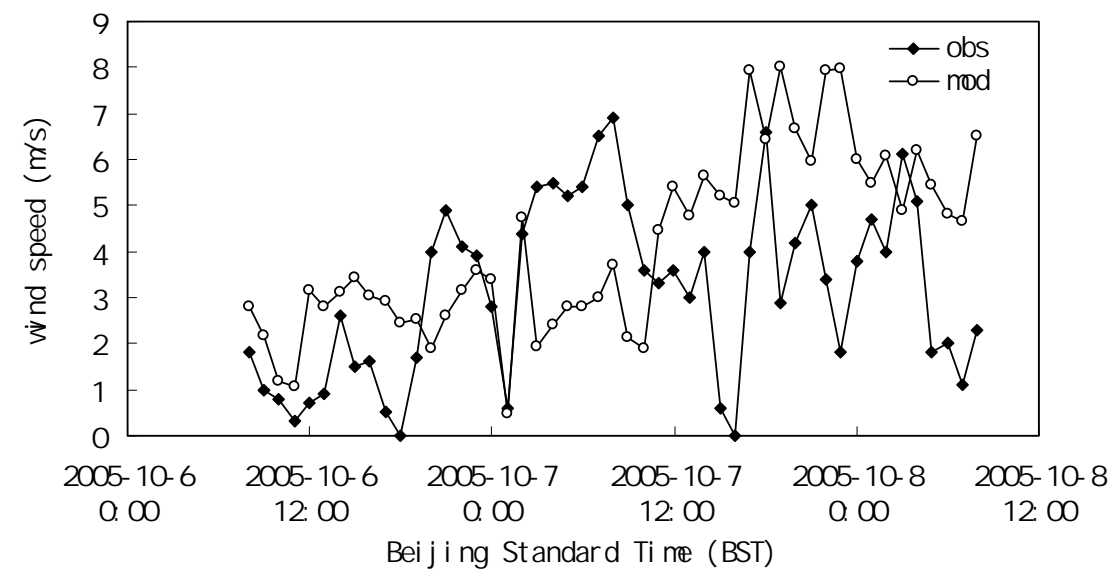

c

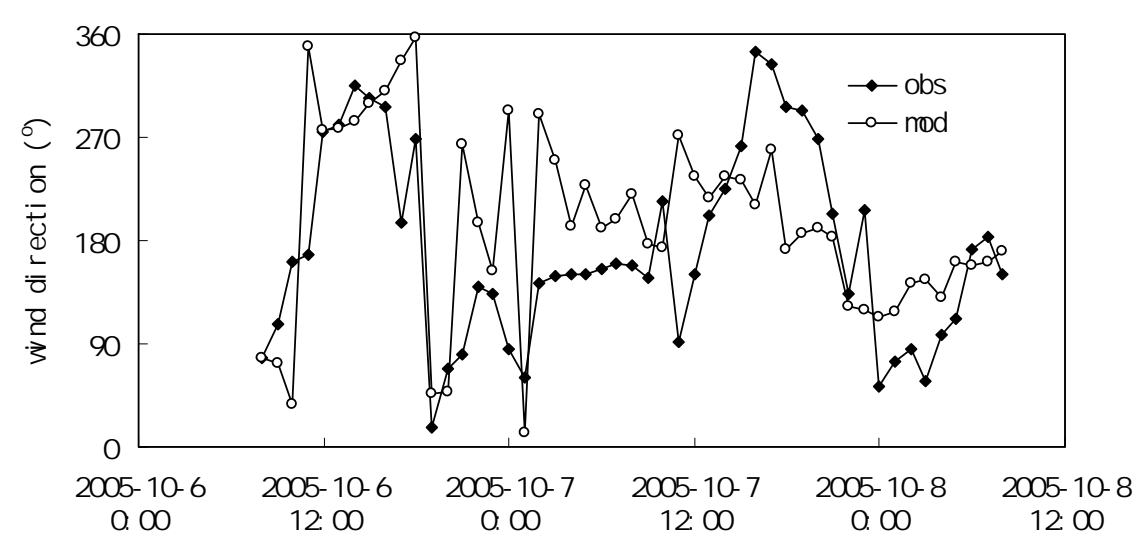

Bei j ing St andard Ti me (BST)

Fig. 3. Modelled versus observed screen $2 \mathrm{~m}$ air temperature (a), $10 \mathrm{~m}$ wind speed (b) and wind direction (c). 
a
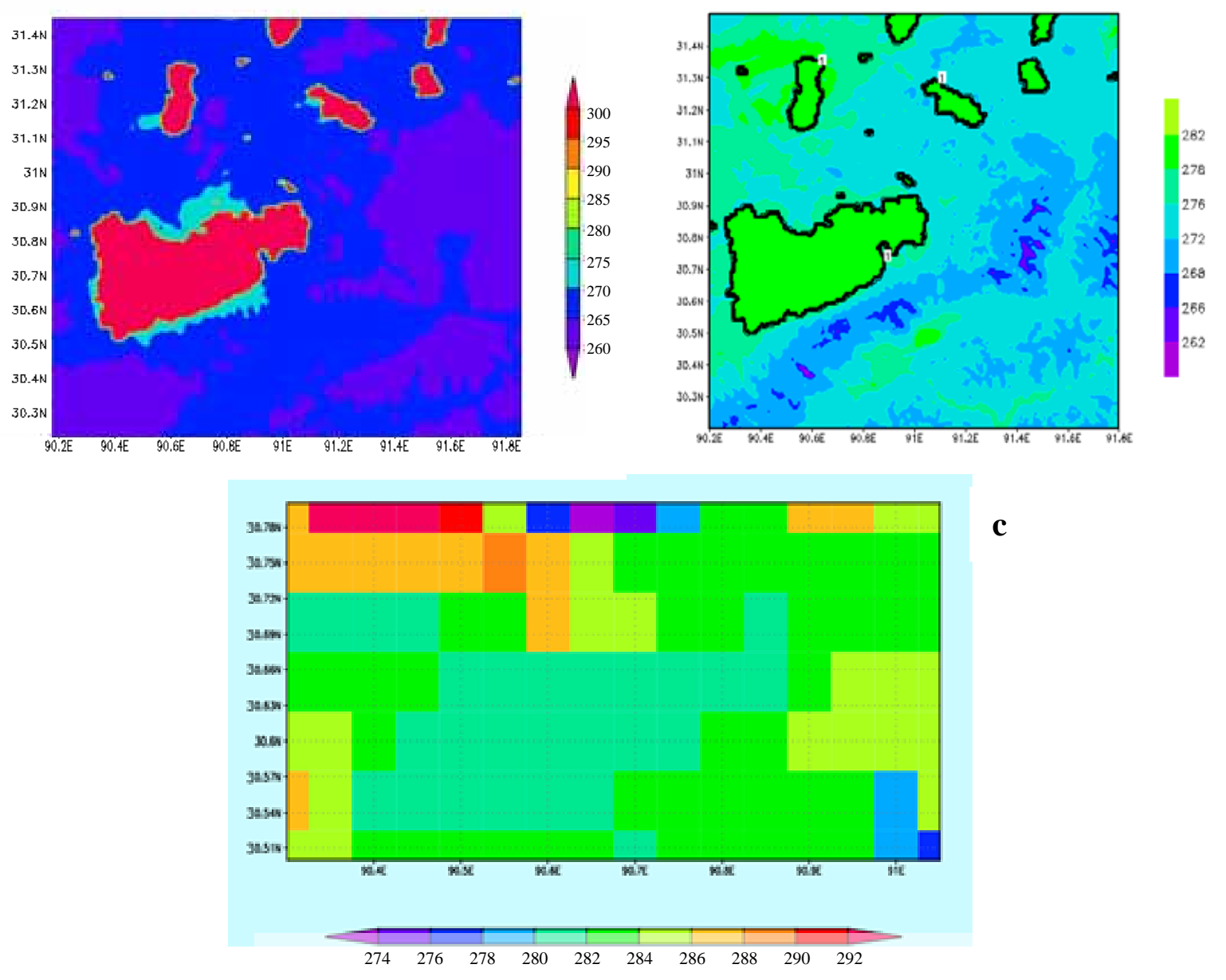

Fig. 4. The output surface temperature from model domain 3 in base experiment (a) and revised experiment (b), remote sensing retrieved surface temperature (c).

\section{Results and discussion}

\subsection{Model evaluation: near-surface meteorology}

After inputting remote sensing retrieved lake skin temperature, we obtained a new air temperature. A comparison of near-surface meteorological fields was carried out between the observations and the WRF simulations for the period 6 October through to 10 October 2005. Figure 3a shows the comparison of the $2 \mathrm{~m}$ screen height air temperature between the model and the observations. During the simulation period, the model agrees reasonably well with the observations but has some cold discriminations, especially at midday. At night the modelled temperature value was higher than that in the observations. The modelled temperature diurnal cycle is perfectly in phase with the observations. The model gives a high estimate of the screen height air temperature at night but does a better job predicting the day temperature.
The comparisons of the observed $10 \mathrm{~m}$ wind speed and direction are more divergent than that demonstrated with temperature (Fig. $3 \mathrm{~b}$ and c). The observed and modelled wind speed average $3.16 \mathrm{~m} / \mathrm{s}$ and $4.14 \mathrm{~m} / \mathrm{s}$, the observed and modelled wind direction average $172^{\circ}$ and $195^{\circ}$, respectively for the entire simulation period. Both observed and modelled winds demonstrate diurnal cycles. During the day, a strong northwesterly wind persists (except it was a southerly wind on 7 October), the nights are calm with more sporadic changes in wind direction. The general trends in observed wind speeds and directions are captured in the simulation, but the model overestimates the wind speeds, and has more changes in wind direction compared to the observations.

\subsection{Comparison of skin temperature between two experiments}

The output surface temperature from model domain 3 is over $300 \mathrm{k}$ in lake area just as the simulated result at the simulated 

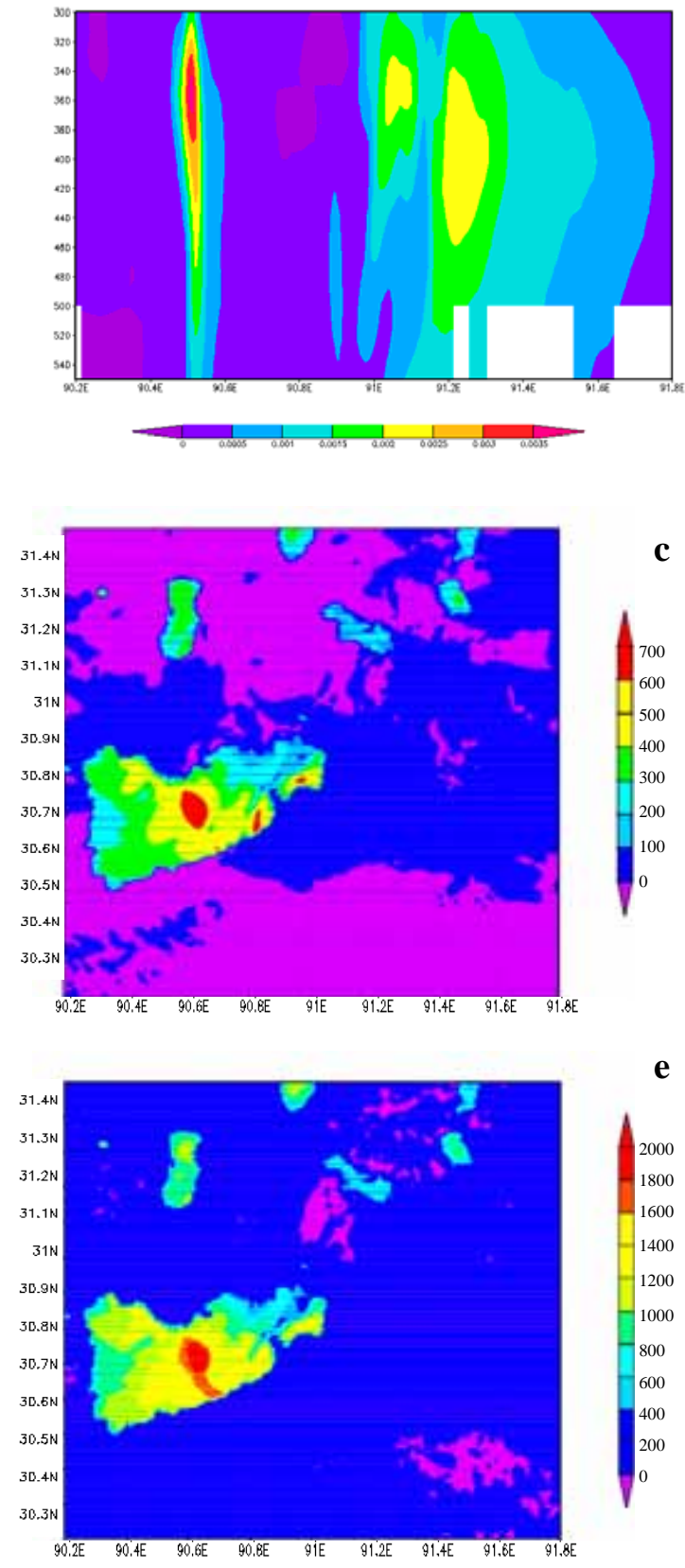

e

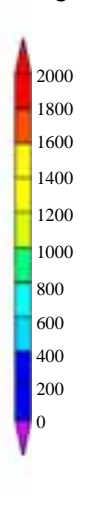

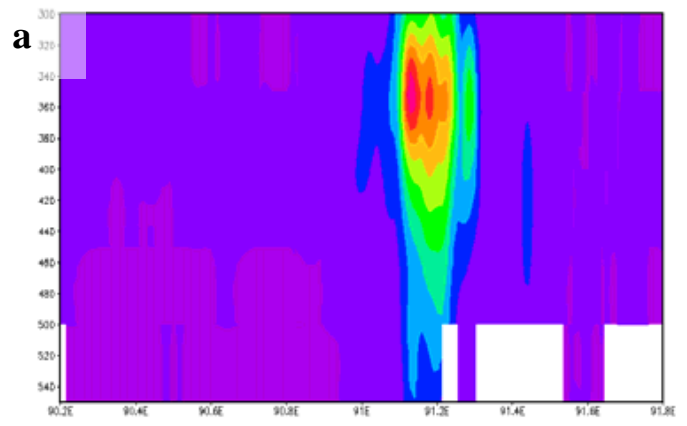

b
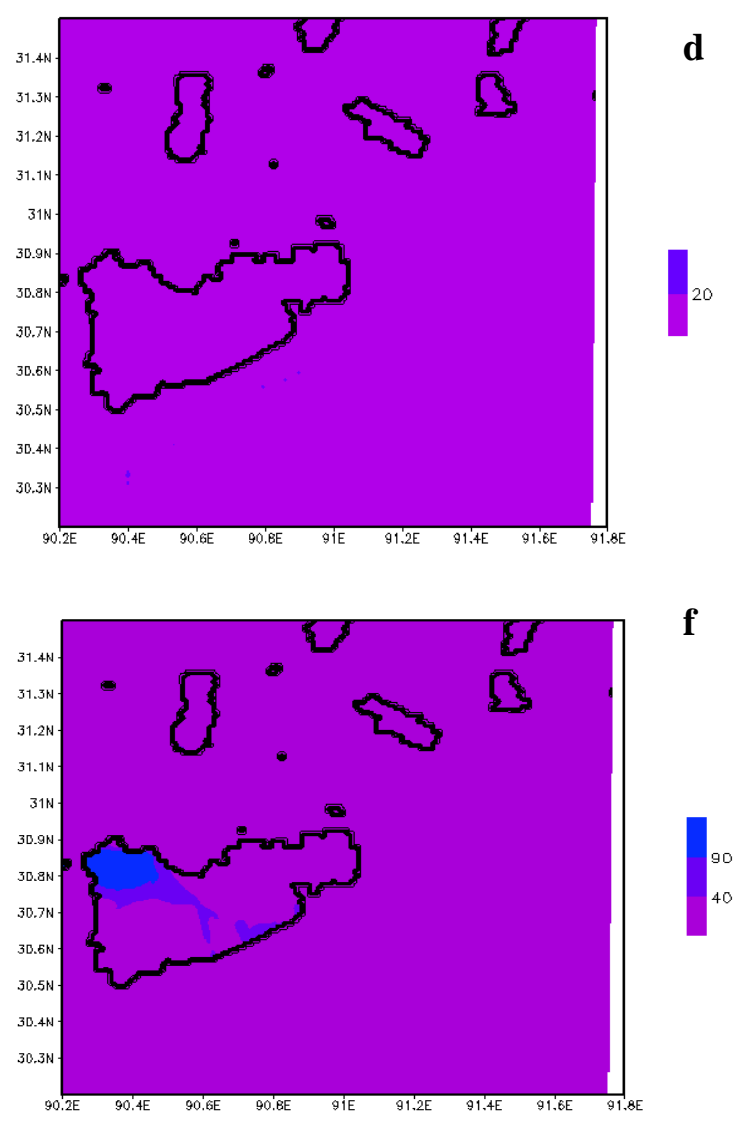

Fig. 5. Mixing rate of snow, sensible heat flux and latent heat flux in the base experiment (a, $\mathbf{c}$ and $\mathbf{e})$ and the revised experiment $(\mathbf{b}, \mathbf{d}, \mathbf{f})$, respectively.

$41 \mathrm{~h}$ (Fig. 4). The surface temperature of the mountain area is lower than it is on the land area. Lake surface temperature (Fig. 4a) compared to remote sensing retrieved surface temperature (Fig. 4c) is unreasonable. After the input of $11 \mathrm{mi}-$ crometer brightness temperature (T11) from FY-2C satellite as lake skin temperature during clear sky condition, output lake surface temperature is consistent with the satellite data (Fig. 4b).

\subsection{Comparison of mixing rate of snow at $550-300 \mathrm{mb}$ and surface heat fluxes}

The surface heating difference in two experiments produce different mixing rates of snow. The mixing rate of the base experiment (Fig. 5a) was larger than it is in the revised experiment (Fig. 5b). On the lake surface, cool air displaces lighter warm air by sliding under the warm air during early winter. More heating over the lake, the more water vapour 


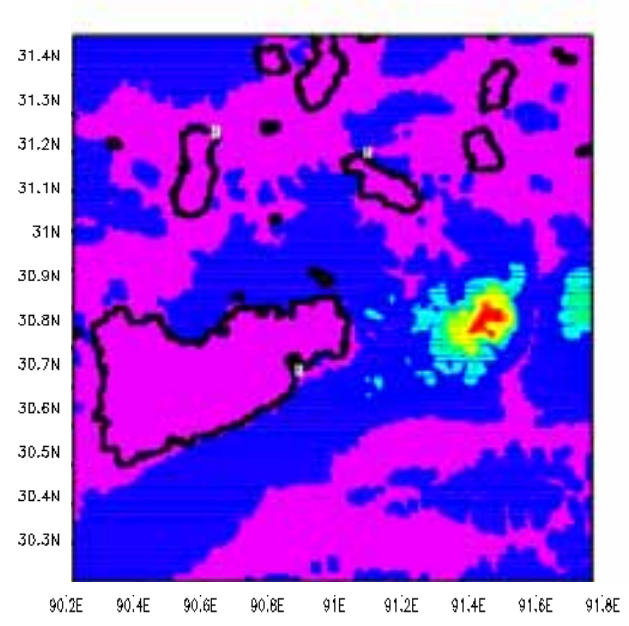

a

b
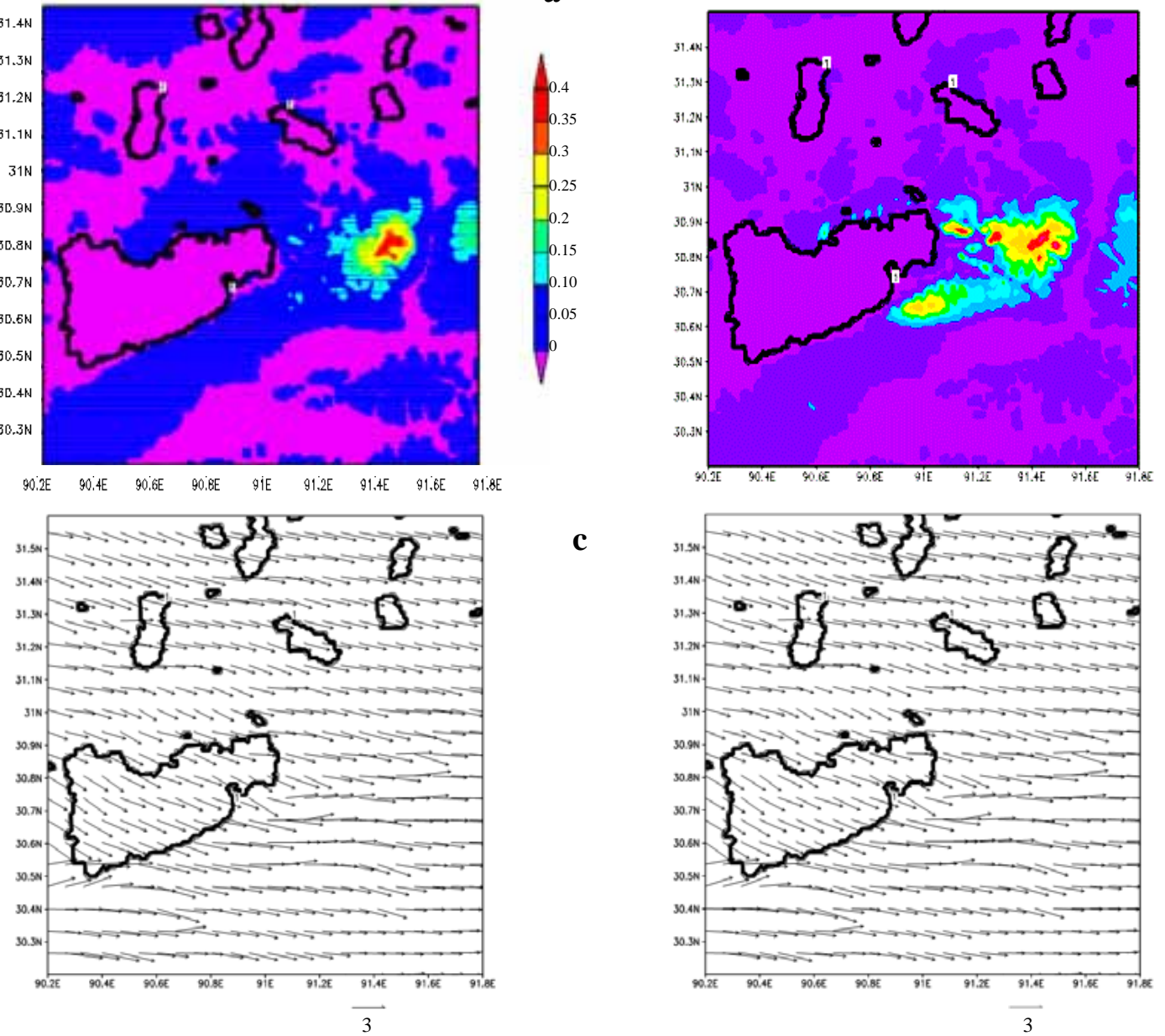

c

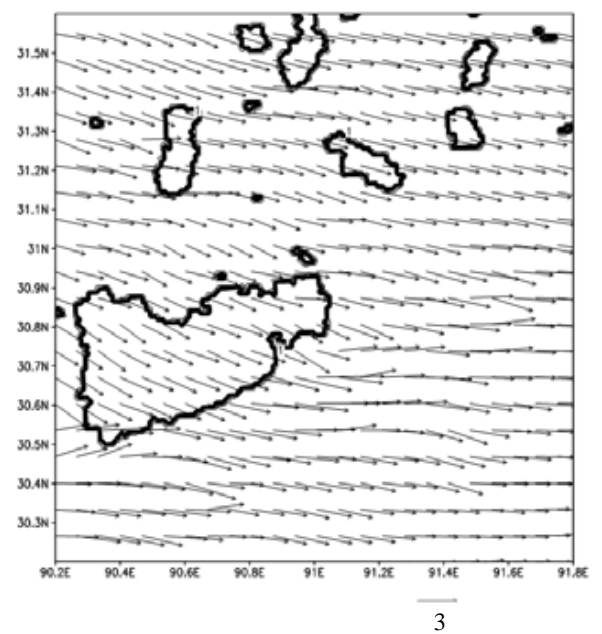

d

Fig. 6. Simulated snow depth and $450 \mathrm{mb}$ wind field in the base experiment (a, c) and the revised experiment (b, d).

transfer upwards. Surface heating field including sensible heat flux and latent heat flux was stronger in the base experiment (Fig. $5 \mathrm{c}$ and e) than that in the revised experiment (Fig. 5d and f).

\subsection{Comparison of snow depth between base experiment and revised experiment}

The maximum amount of snowfall was over the northeastern area of the Namco shore in both experiments. In the base experiment (Fig. 6a), the snow cover is larger than that in the revised experiment (Fig. 6b), while the revised experiment has shallow snow accumulation near the northeastern shore of Namco Lake. We suggest that inveracious melting snow near the bank of lake results from inputting high lake surface skin temperature in the experiment. From $450 \mathrm{mb}$ wind field, there was prevailing northwesterly wind on the lake area. So the maximum amounts of snowfall were over the northeastern shore of the Namco lake in both experiments.

\section{Conclusions}

Lake temperature effect snow on the Namco Lake area during early winter 2005, was investigated using WRF including two numerical simulation experiments. Model evaluation against boundary-layer tower measurements and flux observations showed that modified lake surface skin temperature can increase modelled accuracy.

The mechanisms, that lead to snow maximum amounts centered on the downwind shore of Namco Lake, were explored. Namco Lake temperature effect snow is produced in the early winter when cold, northwesterly winds move across the warmer lake water, providing energy and picking up water vapor which freezes and is deposited on the lee shores.

Our numerical study suggests that detailed, highresolution, mesoscale studies need to be run for long term. Mesoscale numerical experiments can be a powerful tool to determine the unique meteorological conditions associated with each tower, and to study the water and energy distribution on the Tibetan Plateau. 
Acknowledgements. This paper was under the auspices of the Chinese National Key Programme for Developing Basic Sciences (2005CB422003), the National Natural Science Foundation of China (40825015, 40810059006, 40675012 and 40705004) and a cooperative project between China and Japan International Cooperation Agency (JICA and GJHZ0735). Most of the numerical simulation work was carried out in the Disaster Prevention Research Institute, Kyoto University, Japan.

Edited by: Z. Su

\section{References}

Chen, F. and Dudhia, J.: Coupling an advanced landsurface/hydrology model with the Penn State/NCAR MM5 modeling system, Part: Model description and implementation, Mon. Weather Rev., 129, 569-585, 2001.

Chen, T. C. and Yoon, J. H.: Interannual Variation in Indochina Summer Monsoon Rainfall: Possible Mechanism, J. Climate, 13, 1979-1986, 2000.

Flohn, H.: Thermal effects of the Tibetan Plateau during the Asian monsoon season, Aust. Meteorol. Mag., 13, 55-57, 1965.

Goswami, B. N., Wu, G., and Yasunari, T.,: The Annual Cycle, Intraseasonal Oscillations, and Roadblock to Seasonal Predictability of the Asian Summer Monsoon, J. Climate, 19(S), 50785099, 2006.

Hahn, D. G. and Manabe, S.: The role of mountains in the south Asian monsoon circulation, J. Atmos. Sci., 32, 1515-1541, 1975.

Luo, H. and Yanai, M.: The large-scale circulation and heat sources over the Tibetan Plateau and surrounding areas during the early summer of 1979, Part 1: Precipitation and kinematic analysis, Mon. Weather Rev., 111, 922-944, 1983.
Murakami, T.: Effects of the Tibetan Plateau. In Monsoon Meteorology, edited by C. P. Chang and T. N. Krishnamurti, Oxford University Press, New York, 235-270, 1987.

Ose, T.: The comparison of the simulated response to the regional snow mass anomalies over Tibet, Eastern Europe and Siberia, J. Meteorol. Soc. Jpn., 74, 845-866, 1996.

Waliser, D. E., Wu, G., Liu, Y., Park, C.-K.: AGCM simulations of intraseasonal variability associated with the Asian summer monsoon, Cli. Dyn., 21, 423-446, 2003.

Wang, S. and Hongsheng, D.: Chinese Lake Records, Beijing, Science Publishing (in Chinese), 1998.

Wang, W., Barker, D., Bruyere, C., Dudhia, J., Gill, D. J.: Michalakes, User's Guide for Advanced Research WRF(ARW) Modeling System Version 2, Mesoscale \& Microscale Meteorology Division, NCAR, 2006.

Wu, G., Liu, Y., Wang, T., Wan, R., Liu, X., Li, W., Wang, Z., Zhang, Q., Duan, A., and Liang, X.: The Influence of Mechanical and Thermal Forcing by the Tibetan Plateau on Asian Climate, J. Hydro. Meteor.-Spec. Sect., 8, 770-789, 2007.

Yanai, M. and Wu, G.-X.: Effects of the Tibetan Plateau, Chap. 13, in: The Asian Monsoon, edited by: Wang, B., Springer, Chichester, 513-549, 2006.

Ye, D., Matsuno, T., Zeng, Q., Huang, R., and Zhang, R.: Climate variability. Proceedings of International Workshop on Climate Variabilities, China Meteorological Press, 3021 pp., 1993.

Zhang, Y., Li, T., Wang, B., and Wu, G. X.: Onset of the summer monsoon over the Indochina Peninsula: Climatology and interannual variations, J. Climate, 15(11), 3206-3221, 2002. 